grid の既製品が皆無にかんがみ，私は31年 8 月26日東京 医大，本学会第 1 回関東連合会で報告しました。

\section{7. 遮光䉍が影像に及ぼす影響に就いて} 德島市民病院放射線科 大隅 豊 X線撮影に於いて, 殊に身体各部の撮影に当って被写 体に依る二次線の影響が非常に多い事は周知の事である。 演者は従来の遮光筒ではこの二次線の撮影が凮多いだろ うと思ったので，てれを実験的に検討して見たのでてれ を報告せんとする。

\section{8. 频椎推間孔の摄影法}

大阪市立大学医学部放射線倁学教室

山口弘之

最近整形外科より訪れる患者の中，頸腕障害の診断の 為に頸椎推間孔の撮影を要望されるものが多い。しかし 頸椎推間孔の撮影法に関しては寡聞にして成書には見当 らない. 頊椎推間孔の撮影はレの線投射角度の選定が極 めて重要であって, 之を誤る時には所要の目的に達し難 い. 私は先ず基礎として人体骨骼標本を使用して撮影角 度を種々変えて, 即ち頸椎の標準廻転角度の決定ななし, 之に依り人体に応用し聯に発表するものである。

\section{9. 骨癌合時のレ線写真について（第１報）}

徳島市民病院放射線科 池田茂之 骨折の化骨形成時に於いてエックス線像として認めら れないにもかかわらず切開手術に依れば完全に化骨形成 されている場合が時々ある。

吾々は化骨成分の時間的変化を化学的に分析してェッ クス線写真撮影条件との関係を検討するため動物実験的 に研究しつつあるのでしれについて報告する。

\section{0. 高压撮影の技術的一考察}

\section{島津病院放射線科}

世続武二・藤田瑞穂・西村健司

近時高圧撮影の基磼的実験觉終え臨床的にも広く研究 が進められているが，当放射線科に於いては，高圧撮影 装置, 貴船号（波尾切断型蓄電器）を使用して，特に胸 部高圧撮影に就いての撮影技術之撮影条件の検討．又低 電圧大電流装置, 平安号に㹥準高圧撮影を行った結果を 報告する。

11. 古交化財の放射線学的研究 その二

徳島県相生町立宮浜病院放射線科 平井正雄 徳島県立中央病院 古度芳夫 徳島鉄道病院放射線科 横田賢治 徳島市立市民病院放射線科○栄 光 夫
鴨島保健所山本広一

徳島県北島町町立北島病院放射線科 河 崎 瑛 徳島市大久保病院エックス線科 久米重夫 徳島大学附属病院放射線科 大形長年・潼山年生 演者らは，古交化財の放射線学的検索が，広く採択さ れている現状に鑑み，昭和30年の総会に於いて発表した 表題の追試岂行い，乙の技法による非破填検査の実際に ついて結論づけようとする。

\section{2. 断層写真鮮鋭化に関する研究}

德島県小松島赤十字病院 成田公正・花本 進

目的 断首写真を鮮鋭にして彰断を明確にせんとす。

方法 亿，放射口並びに遮光筒広㹨にする

ロ、フィルターの厚さを加減する

結果 1. 放射口並びに遮光筒を狭くする程鮮鋭になる

ロ・フィルターを厚くする事により周用のカブリ を除く事になり鮮鋭になる。

13. 同時多層撮影の成績（第 2 報）

岩手医大 樋口喜代治

14. 新現像主薬を使用した処方 $\mathrm{ID}_{2}$ の検討に就いて 大阪鉄道病院派出彰療所レントゲン室 中田政義・武 良勝 吹田第一鉄道影療所レントゲン室 大西正雄 $\mathrm{ID}_{2}$ の処方は英国イルフォード社商品名 (フェラドン) 化学名（ノフェニール 3 ピラソゾン）なる主薬使用し た現像液で，すでに一般用フィルムの高感度用として PQPM 各現像液の文献怡朝日科学, 写真工業, 朝日力 メラ, 科学画報, 自然等の各誌, 光画荘発行笹井教授著 「高感度フィルムと増感現像」にも詳細なデーターが見 られる。猶利点として概略すればメトールに比して少量 で保存性が良く空気酸化に依って着色せず，アルカリ性 の液によく溶け濃厚な原液を得られる。メトールの様な 毒性がなく，かぶれる心配がない……等記されてあり， 又, Xーレイフィルムにも良いと言われている。年れが我 々は従来の処方及びピラゾン (フェニドレ) と同一の物 で富士フィルム商品名）入りのレンドールと其化(1)現像 液の保存性(2)フィルムに及ばす影響(3)原液に対する使用 液の比等について検討した事を報告す。

15. 日本人の体格（胸部直後）に合うフィルムサイ ズに就いて

前橋保健所 $O$ 大須賀任四郎 高崎保健所 藤 村 勝 沼田保健所 尾身 米一 現行市販フィルムは JIS-K7521 規格によるものであ 